\title{
Foreword
}

\section{Navanethem Pillay}

The genocide in Rwanda started in the night of 6-7 April 1994 after the downing of the plane carrying the Rwandan president Juvenal Habyarimana, the president of Burundi and several others. It stands out as one of the most extreme periods of mass violence in contemporary history. Within three months, between 800,000 and 1,000,000 Tutsi and moderate Hutu were killed and many others tortured, maimed, raped, traumatized and left behind completely devastated. The Rwandan genocide against the Tutsi is known for the speed with which so many people were killed and raped and the involvement of many civilians as well as the brutal and openly conducted nature of the violence used in the atrocities. After World War II, the international community had pledged that such crimes as were committed by the Nazi Regime during the holocaust would never happen again. But it did in the mid-1990s as genocide even took place twice: in Rwanda in 1994 and later during the conflict in the former Yugoslavia - in Srebrenica - in 1995. Despite the existence of the UN, the acknowledgement of international human rights and ratification of many treaties relating to crimes such as genocide and torture and the proclamation of the Agenda for Peace by the UN Secretary General, the atrocities could not be prevented. Despite its presence in Rwanda, the UN did not manage to prevent or halt the genocide; rather it reduced its forces on the ground despite warnings from the UN Peacekeeping force in Rwanda that a genocide was taking place. After the genocide the UN Security Council did, however, try to help restore peace and security within the country by setting up the International Criminal Tribunal for Rwanda (ICTR) on 8 November 1994.

The aims of the Tribunal were to "put an end to such crimes and to take effective measures to bring to justice the persons who are responsible' for the terrible atrocities committed in Rwanda and neighbouring states. The UN Security Council believed that 'the prosecution of those responsible would contribute to the process of national reconciliation and to the restoration and maintenance of peace' and would 'contribute to ensuring that such violations are halted and effectively redressed'. 
Although the Tribunal had a difficult start and some setbacks and can still be criticized on some or maybe even many issues, it can nevertheless be said that it has achieved many of its aims. It has indeed successfully prosecuted both political and military leaders as well as a number of other influential people who were considered to be the most responsible for the atrocities committed in Rwanda. It has thus secured that there was no impunity after the genocide, ensured that many of the perpetrators were exposed in trial proceedings at the ICTR and that the legacy of the genocide has been officially established in the trial records.

This volume focuses on the role of the ICTR in developing international criminal law and addresses many of the important issues and aspects relevant for the prosecution of people responsible for genocide, crimes against humanity and war crimes. It holds contributions from people who have been closely involved in the work of the ICTR, such as Chief Prosecutor Justice Hassan B. Jallow, as well as a number of academics. It thus combines views from both academics and practitioners.

One of the main achievements is that the ICTR established a historical record of the widespread occurrence of genocide in Rwanda between April and July 1994. The ICTR is arguably best known for its interpretation of the law on genocide. With the conviction of Akayesu on 2 September 1998, the ICTR was the very first international criminal tribunal to convict someone for genocide. Its interpretation of the elements of the crime of genocide, including establishing that rape and other forms of sexual violence may amount to genocide, are ground breaking. In the Nahimana et al. ('Media') case, Nahimana and Ngeze were furthermore found guilty of direct and public incitement to commit genocide for their hate speeches via the media. The Akayesu and Media cases can without doubt be considered landmark cases. The ICTR, however, also played a significant role in the development of other international crimes, that is, crimes against humanity and war crimes. More specifically, its consideration of the contextual threshold required for crimes against humanity and its influential development of sexual violence as a crime against humanity (in particular defining the crime of rape in the Akayesu case) and persecution as a crime against humanity (in particular how hate speech fits into this crime as was dealt with in the Media case) stand out. As for war crimes, the ICTR made clear that a linkage between the armed conflict and killings - a requirement for war crimes - can be established from the collision between official security forces (for example soldiers, gendarmes and policemen) with armed militias or civilians involved in the killings. Together with the ICTY the Tribunal, however, also played a very important role in the development 
of the various modes of liability and thus establishing individual criminal responsibility.

The book also shows that the ICTR had to deal with some very specific problems such as the arrest and apprehension of the suspects. Up till now (April 2016) eight suspects are still at large. This fact - as well as the Barayagwiza case - show how politicized the arrest and transfer proceedings can be. Although the ICTR, due to a number of causes, faced serious problems in relation to the investigation and selection of cases, its work improved significantly over the years thanks to hard-working and well-qualified personnel and the active role of the various prosecutors. The Tribunal's trial and appeal processes represent a substantial contribution to the corpus of international criminal procedure, although it is alleged that there are still significant shortcomings in the need to provide smooth, efficient and speedy trials in which the rights of the defence are fully acknowledged. One of the particular problems the ICTR had to deal with was the finding and gathering of evidence. Due to the very particular nature of Rwandan society and mass atrocity crimes in general, the ICTR had to base many of its findings on eye witnesses. Witnesses were sometimes intimidated or disappeared and trials have sometimes dragged on for many years.

This book can, however, help in identifying the major achievements as well as the shortcomings in relation to both the role of the prosecution as well as of the defence and can be used as a reference book establishing the lessons to be learned. It cannot be stressed enough that although the prosecution of those responsible for the terrible atrocities committed in Rwanda is paramount, the ICTR - as well as all other international criminal courts and tribunals - had to acknowledge the human rights of the defendants and guarantee them a fair trial. Reconciliation has to be based on a respect for fundamental human rights. Although international criminal justice will indefinitely fail to do full justice to the victims, the Tribunal can be credited for the translation of basic principles of justice for the victims to practical protocols and procedures that have with time evolved into basic practices for enforcing victims' rights before international criminal tribunals (for example, compensation and participation rights). It is not nearly enough of what can and should be done for the victims, but it is at least a step forward.

Rwanda had made an unprecedented effort to try all those suspected of being involved in the genocide. Next to the 90 suspects who had been indicted by the ICTR, there were prosecutions by the national criminal court as well as many trials before the gacaca courts. This book, however, focuses on the role of the ICTR. The ICTR closed its doors in December 2015 after having pronounced its last appeals judgment in the 
Nyiramasuhuko et al. ('Butare') case. Remaining issues - such as the trials of the suspects still at large - will be looked after by the MICT. This book therefore comes at a timely moment and can be considered to be a work of reference to the legacy of the ICTR. 